CZASOPISMO INŻYNIERII LA¿OWEJ, ŚRODOWISKA I ARCHITEKTURY JOURNAL OF CIVIL ENGINEERING, ENVIRONMENT AND ARCHITECTURE JCEEA, t. XXXIII, z. 63 (3/16), lipiec-wrzesień 2016, s. 43-50

\author{
Marta CHODYKA ${ }^{1}$ \\ Jerzy NITYCHORUK ${ }^{2}$ \\ Fabian WELC ${ }^{3}$ \\ Anna ROGÓ: $\dot{Z}^{4}$ \\ Zofia LUBAŃSKA ${ }^{5}$ \\ Tomasz GRUDNIEWSKI ${ }^{6}$
}

\title{
WPLYW ZMIAN KLIMATU NA OSADNICTWO PREHISTORYCZNE MAZUR W KONTEKŚCIE BADAŃ OSADÓW JEZIORNYCH
}

\begin{abstract}
Badania zmian klimatu odbywają się z dużym sukcesem na osadach jeziornych. Przedstawione w artykule dotychczasowe badania ujmowały zagadnienia antropopresji na dużym obszarze przy uwzględnianiu badań pojedynczych jezior, co dawało wnioski ciekawe ale dosyć ogólne. Zaproponowana w pracy koncepcja badań stawia na pierwszym miejscu bezpośredni związek obiektu archeologicznego z towarzyszącym mu jeziorem. Badanie i tym samym wyszczególnienie faz osadniczych opiera się głównie na analizie materiału archeologicznego pozyskanego w trakcie wykopalisk. W przypadku regionu Warmii i Mazur odtworzenie poszczególnych etapów dawnego osadnictwa utrudnia nie tylko brak źródeł pisanych ale również fragmentaryczność danych archeologicznych. Przedstawione przez autorów analizy palinologiczne i diatomologiczne pozwoliły na wstępną charakterystykę litologiczno - sedymentologiczną osadów dennych tego zbiornika. Wykazały, iż dno jeziora wyściełają głównie osady organogeniczne (gytie), które nie są przewarstwione osadami piaszczystymi, co wskazuje na bardzo spokojne środowisko sedymentacji oraz ciągły zapis procesów depozycyjnych. Co więcej, wykona-
\end{abstract}

${ }^{1}$ Autor do korespondencji / corresponding author: Marta Chodyka, Państwowa Szkoła Wyższa im. Papieża Jana Pawła II w Białej Podlaskiej, Wydział Nauk Ekonomicznych i Technicznych, Zakład Informatyki, ul. Sidorska 95/97, 21-500 Biała Podlaska; tel. 833449907; m.chodyka@dydaktyka.pswbp.pl

2 Jerzy Nitychoruk, Państwowa Szkoła Wyższa im. Papieża Jana Pawła II w Białej Podlaskiej, Wydział Nauk Ekonomicznych i Technicznych, Zakład Budownictwa, ul. Sidorska 95/97, 21-500 Biała Podlaska; ; tel. 833449907; jerzy.nitychoruk@.pswbp.pl

${ }^{3}$ Fabian Welc, Uniwersytet Kardynała Stefana Wyszyńskiego w Warszawie, Instytut Archeologii, ul. Wóycickiego 1/3

${ }^{4}$ Anna Rogóż, Państwowa Szkoła Wyższa im. Papieża Jana Pawła II w Białej Podlaskiej, Centrum Badawcze EKO AGRO TECH, ul. Sidorska 105, 21-500 Biała Podlaska

${ }^{5}$ Zofia Lubańska, Państwowa Szkoła Wyższa im. Papieża Jana Pawła II w Białej Podlaskiej Wydział Nauk Ekonomicznych i Technicznych, Zakład Informatyki, ul. Sidorska 95/97, 21-500 Biała Podlaska

6 Tomasz Grudniewski, Państwowa Szkoła Wyższa im. Papieża Jana Pawła II w Białej Podlaskiej, Wydział Nauk Ekonomicznych i Technicznych, Zakład Informatyki, ul. Sidorska 95/97, 21-500 Biała Podlaska 
ne już pomiary podatności magnetycznej wstępne dane geochemiczne $\mathrm{z}$ analizy SEM/EDS (mikroskop skaningowy z mikrosondą), w celu korelacji opisywanych rdzeni, ujawniły, iż charakteryzują się one niemal identycznym zapisem sedymentacyjnym i tym samym paleośrodwiskowym, co potwierdza fakt, iż w zbiorniku zachodziła ciągła i spokojna sedymentacja, która doskonale odzwierciedla lokalne ale i też regionalne przemiany środowiskowe. Z przeprowadzonych badań wynika, że w osadach jeziornych zanotowane są wyraźne zmiany, które można utożsamiać $\mathrm{z}$ momentami antropopresji oraz/lub zmianami klimatycznymi powiązanymi z wahaniami poziomu wód w jeziorze.

Słowa kluczowe: zmiany klimatu, osady jeziorne, analiza badań, przemiany środowiskowe

\section{Wprowadzenie}

Badania zmian klimatu odbywają się z dużym sukcesem na osadach jeziornych. Zaletą osadów jeziornych jest ich duże tempo sedymentacji, od 0,3 do kilku milimetrów rocznie, które umożliwia badanie zmian $\mathrm{w}$ osadach z dokładnością do miesięcy; dobre warunki do powstawania osadów niezaburzonych, czasami z wyraźną roczną laminacją; stosunkowo duża łatwość w pozyskaniu rdzeni kopalnych osadów jeziornych; możliwość wykonania wszechstronnych badań tych osadów, od paleontologicznych, po geochemiczne, co daje możliwość uchwycenia najmniejszych zmian środowiskowych i klimatycznych. Sztandarowymi przykładami opracowań osadów jeziornych są badania prowadzone w jeziorze pokraterowym Holzmaar w Niemczech [1], czy jeziora Gościąż w Polsce [2,3]. Jednym z ciekawszych opracowań pokazujących zależność sedymentacji jeziornej od aktywności ludzkiej jest praca [4], gdzie przedstawiono wpływ antropopresji w 12 stanowiskach, w okresie ostatnich 5000 lat.

$\mathrm{Na}$ obszarze południowo-zachodniej części pojezierza warmińskomazurskiego, począwszy już do lat 60-tych XX wieku, przeprowadzono szereg projektów, których celem było odtworzenie zmian paleośrodowiskowych w szerokim kontekście chronologicznym, obejmującym okres od schyłku ostatniego zlodowacenia po późne średniowiecze. Szczególnie cenne dane otrzymano z analiz palinologicznej i malakologicznej, które pozwalają z dużą rozdzielczością odtworzyć ewolucje pokrywy leśnej oraz zmiany wahań wód jeziornych.

$\mathrm{Z}$ punktu widzenia analizowanych zagadnień, szczególnie istotne wyniki przyniosły badania osadów dennych jeziora Strażym, położonego na obszarze pojezierza brodnickiego, którymi kierował W. Niewiarowski [5]. Wykonano m.in. analizy geochemiczne, palinologiczne, makroszczątków oraz szereg datowań radiowęglowych. Badania te pozwoliły w pierwszym rzędzie określić wahania poziomu wód jeziora począwszy od końca interstadiału Allerød do okresu subatlantyckiego włącznie. Stwierdzono m.in., że w tym ostatnim okresie poziom wód jeziora był o około 5 metrów wyższy od obecnego i zapewne najwyższy w całym Holocenie. 
Dla porównania: według studiów innych badaczy średni poziom wód jezior mazurskich oscylował od znacząco wyższego niż obecnie w okresie między 750-400 p.n.e., aby opaść następnie o dwa metry (w stosunku do obecnego) w latach 1000-1400 n.e., osiągając swoje maksimum między 1500 a 1800 n.e.

Dzięki badaniom palinologicznym osadów jeziora Strażym udało się zrekonstruować nie tylko sukcesję roślinną w trakcie całego Holocenu, ale również uchwycić bezpośredni wpływ człowieka na środowisko przyrodnicze, tj. określić antropopresję. $\mathrm{Z}$ analiz tych wynika jednoznacznie, że w okresie rzymskim doszło do zakrojonego na szeroką skalę procesu odlesiania w bezpośrednim otoczeniu jezior. Przejawia się to m.in. zanikiem pyłku Ulmus (wiąz), Fraxinus (jesion) i jednoczesnym wzrostem udziałów procentowych pyłków zbóż - Secale cereale (żyto). W okresie wędrówek ludów nastąpiła ponowna regeneracja lasów, co wiąże się najprawdopodobniej z zanikiem osadnictwa na omawianym obszarze. W diagramach pyłkowych zjawisko to uwidacznia się m.in. w ponownej dominacji pyłku dębu i grabu - drzew, które rozpoczęły ponowną ekspansję na obszar gleb użyźnionych wcześniej popiołami na skutek wielkoskalowego karczowania w okresie rzymskim.

Zgodnie z tymi samymi badaniami ponowny okres wycinki zwartych zbiorowisk leśnych datuje się na wczesne średniowiecze, przy czym w XII wieku proces ten został nagle przerwany, jednak nie na tak długo, aby las mógł się ponownie zregenerować. Zjawisko to na diagramach pyłkowych ilustruje m.in. rozprzestrzenianie się pyłku brzozy i grabu. Kolejna faza to ekstensywne odlesienie obszaru wokół jeziora Strażym zapewne w celu powiększania areału uprawnego, co manifestuje się obecnością pyłku zbóż. Fazę tę według B. Noryśkiewicz [6] należy korelować z drugą połową średniowiecza.

Wyniki badań palinologicznych B. Noryśkiewicz zdają się potwierdzać analizy paleoekologiczne przeprowadzone z obszaru Wielkich Jezior Mazurskich. Na południowy wschód od Giżycka, A. Wacnik [7] wykonała badania palinologiczne próbek osadów jeziora Miłkowskiego i Wojnowo, których głównym celem było zbadanie zmian w szacie roślinnej w okresie ekspansji krzyżackiej. Warte nadmienienia jest to, że obecnie obszar znajdujący się wokół obydwu jezior jest niemal całkowicie bezleśny i silnie zmieniony antropogeniczne.

Według A. Wacnik najprawdopodobniej już w XI wieku rozpoczął się intensywny proces przeobrażania szaty roślinnej wokół jeziora Miłkowskiego i Wojnowo. W sąsiedztwie tych jezior, w pierwszej połowie średniowiecza, lasy zostały w dużym stopniu wykarczowane w celu utworzenia pól uprawnych i pastwisk. Proces ten poprzedzał bezpośrednio podbój regionu przez Krzyżaków. Na diagramach pyłkowych proces wzmożonego osadnictwa manifestuje się zwiększonym udziałem pyłku roślin ruderalnych, związanym z bezpośrednim sąsiedztwem siedzib ludzkich (m.in. Urtica, Plantago major, Artemisia i Chenopodiaceae). Ponadto w profilu pozyskanym z dna jeziora Wojnowo odnotowano liczne pozostałości spalonych tkanek roślinnych, które wskazują na intensywne pożary, zapewne wzniecane w procesie karczowania terenu wokół samego jeziora. 
Podsumowując swoje badania A. Wacnik zwraca uwagę na znaczące rozbieżności pomiędzy zapiskami historycznymi wzmiankującymi istnienie w okresie średniowiecza w sąsiedztwie jezior Miłkowskiego i Wojnowo puszczy a danymi palinologicznymi świadczącymi jednoznacznie, że na niektórych obszarach zjawisko powstawania trwałych odlesień jest znacznie wcześniejsze i sięga co najmniej dwa stulecia wstecz.

W północno-wschodniej części pojezierza mazurskiego badane były m.in. osady denne jeziora Kruklin, które znajduje się około $10 \mathrm{~km}$ na wschód od Giżycka. Zespół kierowany przez J. Stasiak [8] wykonał tam m.in. analizy: palinologiczne, makroszczątków, składu botanicznego torfów, stopnia ich rozkładu, dendrochronologiczne, zawartości węglanów $(\mathrm{CaCO} 3)$ oraz datowania radiowęglowe. Wyniki tych badań wskazują, że okres subatlantycki cechował się wilgotnym klimatem i wysokim stanem wody w jeziorze.

Z badań M. Ralskiej-Jasiewiczowej [9] osadów jeziora Mikołajkowskiego wynika, że do XIII wieku włącznie około $80 \%$ powierzchni pojezierza mazurskiego pokrywały zwarte lasy, a pozostałą część stanowiły bagna i jeziora. Tereny trwale zagospodarowane przez człowieka stanowiły wówczas minimalny procent. Wielkoobszarowy karczunek lasów rozpoczęli dopiero koloniści krzyżaccy w XVI wieku. W 1800 roku obszar zajmowany przez zwartą pokrywę leśną skurczył się do 30\%, ulegając w późniejszych czasach dalszemu ograniczeniu.

\section{Badania osadów jeziornych Warmii i Mazur}

Badanie i tym samym wyszczególnienie faz osadniczych opiera się głównie na analizie materiału archeologicznego pozyskanego w trakcie wykopalisk. W przypadku regionu Warmii i Mazur odtworzenie poszczególnych etapów dawnego osadnictwa utrudnia nie tylko brak źródeł pisanych ale również fragmentaryczność danych archeologicznych. Wyniki przeprowadzonych dotychczas badań wykopaliskowych, pozwalają jedynie w wielkim przybliżeniu określić momenty intensywnego osadnictwa na omawianym terenie. Aby uchwycić z jednej strony aktywność dawnego człowieka, poznać wpływ jaki wywierał na środowisko (antropopresja) oraz uzyskać wgląd w kwestie jak zmiany środowiskowe i klimatyczne stymulowały lub hamowały procesy osadnicze, planuje się odczytać bogate, a dotychczas mało wykorzystane archiwum jakim są osady jeziorne Warmii i Mazur.

Wykonane już wstępne badania osadów pozyskanych w formie czterech kilkumetrowych rdzeni z dna Jeziora Młynek w okolicach wsi Janiki Wielkie (rys. 1) nie pozostają żadnych wątpliwości, co do ich unikalnej wartości poznawczej. 


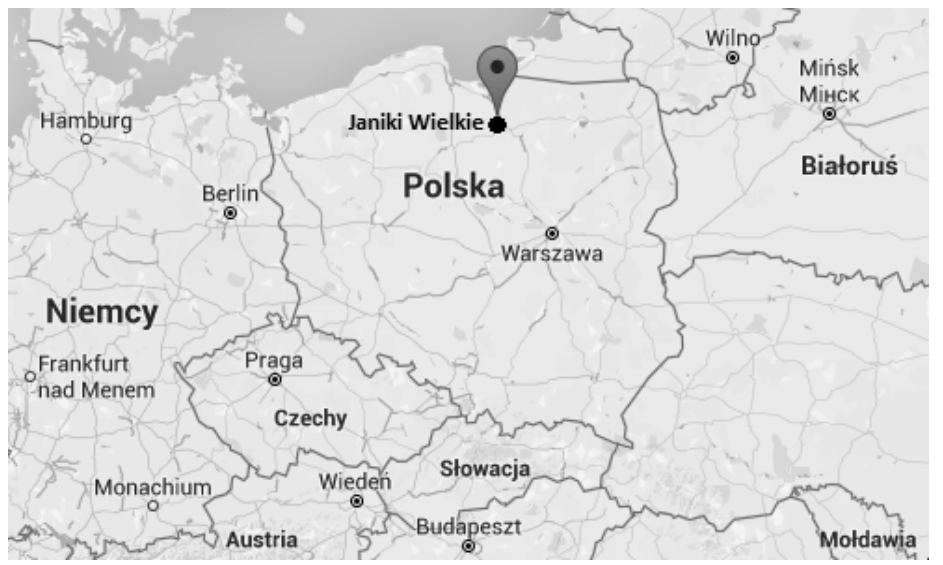

Rys. 1. Lokalizacja Janiki Wielkie

Fig. 1. Location of Janiki Wielkie

JANIKI WIELKIE / JW - 1
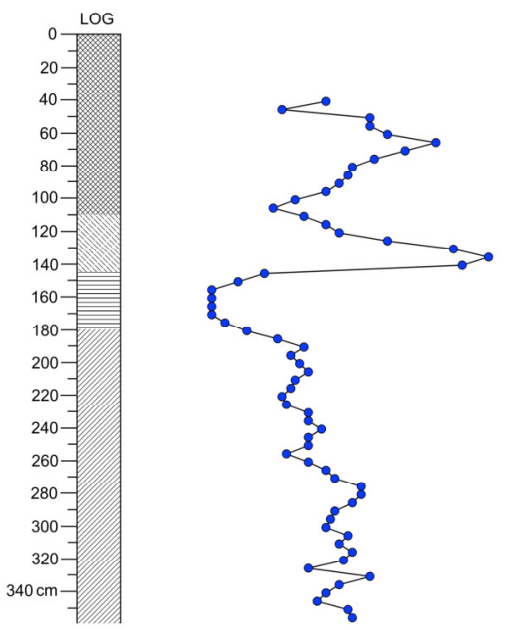

LEGEND

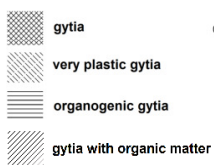

Rys. 2. Pomiar podatności magnetycznej

Fig. 2. Measurement of magnetic susceptibility
$60 \%$

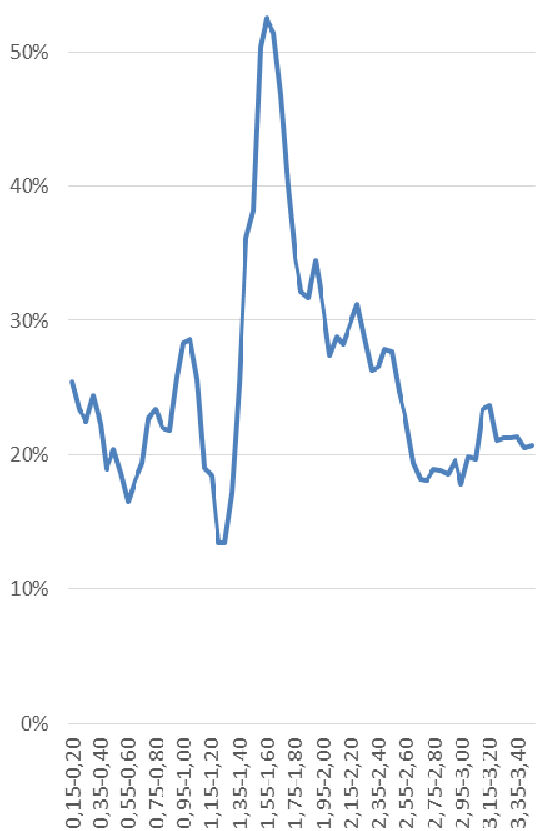

Rys. 3. Pomiar strat prażenia $w \%$, oś pozioma - głębokość w m

Fig. 3. Measurement of loss-on-ignition in $\%$, the horizontal axis - depth in $\mathrm{m}$ 
Dla tych osadów wykonano podstawowe badania, na które złożyły się pomiary podatności magnetycznej (rys. 2), pomiar strat prażenia w celu określenia ilości materii organicznej (rys. 3), zawartość węgla organicznego (TOC) i analiza SEM/EDS.

Dla rdzenia Janiki Wielkie/JW 1 wykonano również analizę palinologiczna i diatomologiczną. Badania te pozwoliły na wstępną charakterystykę litologiczno - sedymentologiczną osadów dennych tego zbiornika. Wykazały, iż dno jeziora wyściełają głównie osady głównie organogeniczne (gytie), które nie są przewarstwione osadami piaszczystymi, co wskazuje na bardzo spokojne środowisko sedymentacji oraz ciągły zapis procesów depozycyjnych. Co więcej, wykonane już pomiary podatności magnetycznej wstępne dane geochemiczne $\mathrm{z}$ analizy SEM/EDS (mikroskop skaningowy z mikrosondą), w celu korelacji opisywanych rdzeni, ujawniły, iż charakteryzują się one niemal identycznym zapisem sedymentacyjnym i tym samym paleośrodwiskowym, co potwierdza fakt, iż w zbiorniku zachodziła ciągła i spokojna sedymentacja, która doskonale odzwierciedla lokalne ale i też regionalne przemiany środowiskowe. Wyraźny wzrost wartości podatności magnetycznej, zaobserwowany na głębokości ok. $1 \mathrm{~m}, \mathrm{z}$ jednej strony może odzwierciedlać zmiany klimatyczno - hydrologiczne w obrębie zbiornika, z drugiej może się wiązać ze wzmożoną aktywnością dawnego człowieka.

\section{Wnioski}

Dotychczasowe badania ujmowały zagadnienia antropopresji na dużym obszarze przy uwzględnianiu badań pojedynczych jezior, co dawało wnioski ciekawe ale dosyć ogólne. Zaproponowana koncepcja badań stawia na pierwszym miejscu bezpośredni związek obiektu archeologicznego z towarzyszącym mu jeziorem. Jezioro w tej sytuacji jest archiwum, w którym zanotowane są wszystkie zdarzenia mające miejsce w jego pobliżu. Sedymentacja osadów jeziornych jest w miarę stała, co sprawia, że zapis antropopresji można odczytywać nie tylko jako moment, ale również określić jego długość i intensywność. Innowacyjność prowadzonych badań polega właśnie na odtworzeniu historii osadnictwa na bazie relacji jezioro - obiekt archeologiczny, czyli zamkniętego, pozostającego w związku ze sobą zespołu.

Z opisu rdzenia Janiki Wielkie/JW 1 i przeprowadzonych analiz wynika, że w osadach jeziornych zanotowane są wyraźne zmiany, które można utożsamiać $\mathrm{z}$ momentami antropopresji oraz/lub zmianami klimatycznymi powiązanymi $\mathrm{z}$ wahaniami poziomu wód w jeziorze. W rdzeniu JW 1/15, o długości $3,5 \mathrm{~m}$, wykonano 4 datowania 14-C, pokazujące, że osady na głębokości $3,5 \mathrm{~m}$ powstawały 300 lat przed naszą erą. Stwierdzone w profilu zmiany litologiczne, geochemiczne, zawartości węgla organicznego oraz datowania radiowęglowe wskazują, że okres wczesnej aktywności ludzkiej w naszej erze, przypada na XI - XIII w. Pobrany rdzeń okazał się jednak zbyt krótki, żeby można było da- 
tować ślady wcześniejszych działań człowieka. Na podstawie dotychczasowych badań udało się stwierdzić bardzo wyraźne zmiany w rdzeniu z jeziora Młynek koło Janików Wielkich, odpowiadające przyjętym założeniom o wpływie człowieka i/lub klimatu na sedymentację w jeziorze. Te wstępne dane są bardzo interesujące ze względów sedymentologicznych, paleoklimatycznych i archeologicznych. Zanotowane są w tym profilu ślady aktywności człowieka, pozwolą na określenie ich momentu i długości.

\section{Literatura}

[1] Lottermoser, B.G., Oberhänsli, R., Zolitschka, B., Negendank, J.F.W., Schütz, U. \& Boenecke, J.: Environmental geology and geochemistry of lake sediments (Holzmaar, Eifwl, Germany) Lecture Notes in Earth Sciences 49, 1993, 305-316.

[2] Różański, K., Goslar, T., Duliński, M., Kuc, T., Pazdur, M.F. \& Walanus, A.:The late Glacial-Holocene transition in central Europe derived from isotope studies of laminated sediments from Lake Gościąż (Poland). In: E. BARD \& W.S. BROECKER (Eds), The Last Deglaciation: Absolute and Radiocarbon Chronologies. 69-80. Springer-Verlag; Berlin - Heidelberg. 1992.

[3] Różański, K., Kuc, T., Duliński, M. \& Wachniew, P.: Oxygen and carbon isotope composition of authigenic carbonates in the Holocene part of the Lake Gościąż sediments. In: M. Ralska-Jasiewiczowa, T. Goslar, T. Madeyska \& L. Starkel (Eds), Lake Gościąż, Central Poland a monographic study, part 1, 1998, 229-232.

[4] Zolitschka B., Behre K.E. , Schneider J.: Human and climatic impact on the environment as derived from colluvial, fluvial and lacustrine archives - examples from the Bronze Age to the Migration period, Germany, „QSR", t. 22, 2003, s. 81-100.

[5] Niewiarowski, W.: Development of lake Strażym (Brodnica lake district) during the late - glacial and Holocene. Acta Pelobotanica, vol. 27, no. 1., 1987, 251-304.

[6] Noryśkiewicz, B.: History of vegetation during the Late -Glacial and Holocene in the Brodnica lake district in the light of pollen analysis of the lake Strażym deposits. Acta Pelobotanica, vol. 27, no. 1.,1987, 283-303.

[7] Wacnik, A.: Galandowie i Krzyżacy - oddziaływania na lokalną roślinność w rejonie Miłek i Staświn (Kariana Wielkich Jezior Mazurskich, północno - wschodnia Polska). Wiadomości Botanicze 53 (1/2)., 2009, 21 - 34.

[8] Stasiak, J.: Historia jeziora Kruklin w świetle osadów strefy litoralnej. Prace Geograficzne nr. 42.,Warszawa, 1963.

[9] Ralska-Jasiewiczowa, M.: Bottom sediments of the Mikołajki Lake (Masurian Lake District) in the light of palaeobotanical investigations. Acta Palaeobot. vol. 7, no. 2., 1966, 1-118. 


\section{AN IMPACT OF CLIMATE CHANGE IN A PREHISTORIC MAZURIAN SETTLEMENT IN THE CONTEXT OF LACUSTRINE SEDIMENTS}

\section{S u m m a r y}

Research on climate change done on lake sediments may be successful. The following article presents the research of an antropogenic impact conducted so far on individual lakes, which yielded interesting yet rather general findings. The proposed research forwards a concept that directly links the archaeological site and the nearby lake. The research, particularly the specification of settlement phases, bases on the analysis of archaeological material obtained in excavations. In the case of Warmia and Mazury region, reconstruction of different stages of the former settlement is hindered by the lack of written sources and fragmentary archaeological data. The palynological and diatomological analysis presented by the authors allows for a characterization of lithological sedimentological bottom sediments. It shows that the lake bottom is lined mostly with organogenic sediments (gyttjas), not interbedded with sandy sediments, which indicates a very calm sedimentation and continuous depositional processes. Moreover, the already conducted measurements of the magnetic susceptibility of the preliminary geochemical data from the analysis of SEM / EDS (a scanning electron microscope with a microprobe), enabling a correlation of the described cores, reveals that they are characterized by an almost identical sedimentation and paloeenvironmental record, which proves that the reservoir underwent a calm sedimentation process, which at the same time reflects the local but also regional environmental change. The study shows that significant changes have been noted in the lake sediments, which can be related to an antropogenic impact and / or climate change associated with fluctuations in the water level in the lake.

Keywords: climate change, lake sediments, research analysis, environmental change

DOI:10.7862/rb.2016.184

Przestano do redakcji: $30.06 .2016 r$.

Przyjęto do druku: 30.11.2016 r. 